\title{
RESIDU LOGAM BERAT PADAIKAN DAN KUALITAS LINGKUNGAN PERAIRAN MUARA SUNGAI BARITO KALIMANTAN SELATAN
}

\author{
Dwiyitno*), Nugroho Aji**), dan Ninoek Indriati*)
}

\begin{abstract}
ABSTRAK
Penelitian evaluasi kandungan residu logam berat pada ikan dan lingkungan perairan telah dilakukan di muara Sungai Barito, Kalimantan Selatan. Parameter yang diamati meliputi residu logam berat $(\mathrm{Hg}, \mathrm{Cd}, \mathrm{Cu}$, dan $\mathrm{Pb})$ pada ikan, air, dan sedimen. Di samping itu juga dilakukan analisis kualitas air yang meliputi suhu, kecerahan, $\mathrm{pH}$, salinitas, DO, BOD, dan COD serta unsur hara yang terdiri atas amonia, nitrit, nitrat, sulfit, dan fosfat. Pengambilan sampel dilakukan sebanyak 2 kali, yaitu pada bulan April dan September 2005. Hasil penelitian menunjukkan bahwa kandungan logam berat $(\mathrm{Hg}, \mathrm{Cd}, \mathrm{Cu}$, dan $\mathrm{Pb})$ pada ikan dari perairan muara $\mathrm{S}$. Barito belum melewati ambang batas yang diijinkan, sehingga masih aman untuk dikonsumsi. Namun demikian pada ikan haruan (Ophiocephalus striatus), tingkat konsumsinya harus mendapat perhatian karena kandungan logam berat $\mathrm{Hg}$-nya sudah cukup tinggi. Secara umum, kandungan logam berat pada air dan sedimen muara S. Barito pada stasiun-stasiun yang diteliti masih di bawah ambang batas yang diijinkan, kecuali kandungan $\mathrm{Cd}$ air pada bulan September. Kualitas perairan muara S. Barito secara umum masih cukup baik, kecuali kandungan COD dan amonia pada beberapa stasiun.
\end{abstract}

ABSTRACT: Heavy metal residue in fish and environmental quality of Barito River, South Kalimantan Province. By: Dwiyitno, Nugroho Aji and Ninoek Indriati

Study on the evaluation of heavy metal residue in fish and the environment had been conducted at Barito River, South Kalimantan Province. Parameters observed were heavy metal residue $(\mathrm{Hg}, \mathrm{Cd}, \mathrm{Cu}$ and $\mathrm{Pb})$ of fish and environment including sediment and water. Evaluation of water quality included temperature, trasparency, $\mathrm{pH}$, salinity, $D O, B O D$ and $C O D$, while evaluation of nutrients of the waters (ammonia, nitrite, nitrate, sulfite and phosphate) was also carried out. Samplings were undertaken for 2 times i.e. in April and September 2005. Results showed that heavy metal residue of fish caught from Barito River did not exceed the recommended standard; therefore it is considered safe to consume. However, consumption of certain species, especially haruan (Ophiocephalus striatus), should be limited due to high concentration of $\mathrm{Hg}$ contaminant. In general, heavy metal residue of the water and sediment did not exceed the recommended standard, except for Cd of water in September. Likewise, the nutrient of the river was also in good condition, except COD and ammonia content in some stations.

KEYWORDS: $\quad$ heavy metal, Barito River, fish, water, sediment, $\mathrm{Hg}, \mathrm{Cd}, \mathrm{Pb}$ and $\mathrm{Cu}$

\section{PENDAHULUAN}

Kualitas suatu perairan menjadi sangat penting karena berkaitan dengan biota yang hidup di dalamnya. Wilayah pesisir umumnya merupakan daerah tangkapan ikan yang penting karena memiliki kandungan unsur hara yang baik bagi kehidupan ikan. Unsur hara tersebut biasanya terbawa arus sungai dan mengalir ke laut. Selain unsur hara yang bermanfaat, bahan yang tidak bermanfaat atau bahkan merugikan seperti logam berat juga akan terbawa ke laut apabila dibuang dan masuk ke perairan sungai. Kondisi ini dapat mempengaruhi kualitas lingkungan perairan dan mengganggu ekosistem pada wilayah tersebut. Perairan yang tercemar akan mengakibatkan tercemarnya biota yang hidup di perairan tersebut dan menjadi tidak aman bagi konsumen yang mengkonsumsinya.

Mencuatnya kasus cemaran logam berat merkuri (Hg) dan arsen (As) di Teluk Buyat pada tahun 2004 telah membuka perhatian publik pada potensi-potensi cemaran logam berat yang ada di tempat lain. Cemaran logam berat As di Teluk Buyat (pada sedimen) pada saat itu mencapai 666 ppm, sementara ambang batas cemaran As pada sedimen menurut ASEAN Marine Water Quality Criteria adalah 50 ppm, sedangkan menurut US, Kanada, Australia dan Selandia Baru, ecological Probable Effects Level/PEL As adalah $42 \mathrm{ppm}$. Pada saat itu juga, cemaran logam Hg (pada sedimen) di Teluk Buyat mencapai

\footnotetext{
") Peneliti pada Balai Besar Riset Pengolahan Produk dan Bioteknologi Kelautan dan Perikanan, DKP

m) Perekayasa pada Ditjen Pengawasan dan Pengendalian Sumber Daya Kelautan dan Perikanan, DKP
} 
1.000 ppb (ambang batas 200 ppb) (Anon., 2004; Anon., 2008a).

Pada industri pertambangan terutama logam mulia seperti emas, logam merkuri biasanya digunakan untuk mengikat emas serta memisahkan dari pengotornya (amalgamisasi atau proses pembentukan campuran logam $\mathrm{Hg}$ dengan emas). Limbah proses amalgamisasi tersebut (tailing) sering dibuang ke sungai yang selanjutnya mengalir ke laut. Sebagian besar sungai di Kalimantan Selatan, baik yang besar maupun yang kecil, terutama di tiga kabupaten/kota yakni Tanah Laut, Kota Baru, dan Banjar diduga tercemar merkuri. Hal ini karena industri pertambangan emas banyak terdapat di Kalimantan Selatan. Di tiga daerah tersebut tersebar ratusan penambang emas, baik yang dikelola oleh perorangan maupun perusahaan, yang diduga ilegal, menggunakan air raksa dan membuangnya ke sungai-sungai (Kompas, 2003).

Dari 11 daerah aliran sungai (DAS) di Kalimantan Tengah dan Selatan, 4 DAS diantaranya perlu diwaspadai secara serius kandungan merkurinya. Empat DAS tersebut adalah DAS Kahayan, Kapuas, Arut, dan Barito (Kompas, 2005). Kota Banjarmasin, S. Martapura dan S. Barito juga tak luput dari pencemaran air raksa akibat penambangan emas di hulu S. Kahayan, Kabupaten Kapuas. Di samping itu potensi cemaran pada S. Barito, terutama logam berat, juga berasal dari kegiatan industri lain serta kegiatan transportasi air yang cukup padat sepanjang tahun (Kompas, 2004; Radar Banjarmasin, 2008). Meskipun pada tahun 2007 cemaran merkuri di DAS S. Barito mulai menurun, tetapi masih di atas baku mutu. Cemaran merkuri pada air di wilayah DAS Barito mencapai 5,5 ppb, padahal ambang batas maksimal merkuri pada air adalah 2,0 ppb (Tempo, 2008).
Logam $\mathrm{Hg}, \mathrm{Pb}, \mathrm{Cd}$, dan Cu termasuk jenis-jenis cemaran utama pada lingkungan perairan laut/pantai yang sangat diperhatikan di banyak negara (Anon., 2008a; Carere et al., 2008). Logam-logam ini banyak digunakan pada berbagai kegiatan industri seperti pertambangan, kimia, elektronik, fotografi, pestisida, tekstil, plastik, gelas, dan lain-lain (Eckenfelder, 1989). Konsumsi ikan maupun produk olahan ikan yang tercemar logam berat berpotensi menimbulkan berbagai penyakit baik jangka pendek maupun jangka panjang. Kelainan syaraf, kelumpuhan, dan cacat bawaan pada bayi merupakan contoh penyakitpenyakit yang dapat ditimbulkan akibat kontaminasi logam berat. Oleh sebab itu, perlu dilakukan penelitian pada lokasi-lokasi yang berpotensi tercemar logam berat seperti muara S. Barito, Kalimantan Selatan. Dengan demikian dapat diketahui tingkat pencemaran logam berat pada lingkungan perairannya serta status keamanan ikan yang ditangkap dari perairan tersebut.

\section{BAHAN DAN METODE}

Riset ini merupakan studi kasus terhadap sampel yang diambil dari lokasi-lokasi yang berpotensi tercemar logam berat, khususnya $\mathrm{Hg}, \mathrm{Pb}, \mathrm{Cd}$, dan $\mathrm{Cu}$. Pengamatan kandungan/residu logam berat dilakukan baik pada produk perikanan (ikan segar) maupun lingkungan perairan (air dan sedimen) yang diambil dari lokasi sampling. Pengambilan sampel dilakukan di muara S. Barito sebanyak 3 stasiun serta pada lokasi 1 mil di depan muara juga sebanyak 3 stasiun. Pengambilan sampel dilakukan dua kali yaitu pada bulan April dan September 2005. Lokasi geografis pengambilan sampel disajikan pada Tabel 1. Sedangkan gambar lokasi pengambilan sampel seperti terlihat pada Lampiran 1.

Tabel 1. Koordinat sampling untuk air dan sedimen di Muara Sungai Barito

Table 1. Sampling coordinate of water and sediment at Barito River

\begin{tabular}{|c|c|c|c|}
\hline $\begin{array}{l}\text { Stasiun/ } \\
\text { Station }\end{array}$ & $\begin{array}{c}\text { Bujur Timurl } \\
\text { East Longitude }\end{array}$ & $\begin{array}{l}\text { Lintang Selatan/ } \\
\text { South Latitude }\end{array}$ & $\begin{array}{c}\text { Keterangan/ } \\
\text { Remark }\end{array}$ \\
\hline 1 & E $114^{0} 29^{\prime} 250 "$ & $S 3^{0} 32^{\prime} 000^{\prime \prime}$ & $\begin{array}{l}\text { Tepi muara sungai/ } \\
\text { Side of estuary bank }\end{array}$ \\
\hline 2 & E $114^{\circ} 29^{\prime} 700^{\prime \prime}$ & S $3^{0} 32^{\prime} 250^{\prime \prime}$ & $\begin{array}{l}\text { Tengah muara sungai/ } \\
\text { Center of estuary bank }\end{array}$ \\
\hline 3 & E $114^{\circ} 30^{\prime} 150^{\prime \prime}$ & $S 3^{0} 32^{\prime} 500^{\prime \prime}$ & $\begin{array}{l}\text { Tepi muara sungai// } \\
\text { Side of estuary bank }\end{array}$ \\
\hline 4 & E $114^{\circ} 30^{\prime} 000^{\prime \prime}$ & $S 3^{0} 33^{\prime} 500^{\prime \prime}$ & $\begin{array}{c}1 \text { mil dari muara/ } \\
1 \text { mile from estuary bank }\end{array}$ \\
\hline 5 & E $114^{0} 29^{\prime} 550^{\prime \prime}$ & $S 3^{0} 33^{\prime} 250^{\prime \prime}$ & $\begin{array}{c}1 \text { mil dari muara/ } \\
1 \text { mile from estuary bank }\end{array}$ \\
\hline 6 & E $114^{\circ} 29^{\prime} 100^{\prime \prime}$ & $S 3^{0} 33^{\prime} 000^{\prime \prime}$ & $\begin{array}{c}1 \text { mil dari muara/ } \\
1 \text { mile from estuary bank }\end{array}$ \\
\hline
\end{tabular}




\section{Pengambilan Sampel dan Prosedur Analisis}

Sampel air diambil dengan menggunakan water sampler (Nansen). Pengambilan sampel air dilakukan pada kedalaman 1 meter di bawah permukaan air. Analisis kualitas air yang meliputi salinitas, $\mathrm{pH}$, nitrat, nitrit, fosfat, amonia, sulfit, BOD, dan COD dilakukan segera setelah contoh air diambil. Analisis residu logam berat dilakukan di laboratorium Balai Besar Riset Pengolahan Produk dan Bioteknologi Kelautan dan Perikanan, Jakarta. Sampel air untuk analisis residu logam berat $\mathrm{Pb}, \mathrm{Cd}$, dan $\mathrm{Cu}$ diawetkan dengan larutan asam nitrat $\left(\mathrm{HNO}_{3}\right) \quad 0,3 \% \mathrm{v} / \mathrm{v}$ hingga $\mathrm{pH}$ mencapai 2-3. Sedangkan untuk analisis logam berat $\mathrm{Hg}$, contoh air diawetkan dengan larutan $\mathrm{H}_{2} \mathrm{SO}_{4} 0,25 \%$ v/v (Hutagalung et al., 1997).

Sampel sedimen diambil dengan menggunakan alat pengambil sedimen ( $g r a b$ ) yang terbuat dari stainless steel. Selanjutnya sedimen sebanyak sekitar $500 \mathrm{~g}$ diambil dan disimpan pada wadah plastik, kemudian disimpan pada suhu chilling dalam peti berinsulasi (coolbox) dan dibawa ke laboratorium. Analisis residu logam berat terhadap sampel sedimen dilakukan sesuai dengan SNI 06-6989.46-2005 (untuk logam Pb, Cd, dan Cu) dan SNI 19-6964.2-2003 (untuk logam berat $\mathrm{Hg}$ ).

Sampel ikan diperoleh dari lokasi di sekitar tempat sampling. Ikan diperoleh dari nelayan setempat yang beroperasi di sekitar lokasi sampling. Ikan kemudian diawetkan dengan disimpan pada suhu chilling dalam peti berinsulasi untuk selanjutnya dibawa ke laboratorium. Metode analisis kandungan logam berat $(\mathrm{Pb}, \mathrm{Cd}$, dan $\mathrm{Cu})$ dilakukan berdasarkan SNI 066989.46-2005. Sementara itu analisis logam berat $\mathrm{Hg}$ dilakukan sesuai dengan SNI 19-6964.2-2003. Analisis dilakukan dengan menggunakan Spektrofotometer
Serapan Atom (AAS) Perkin Elmer A-800 (Perkin Elmer, 2000).

Analisis kualitas lingkungan perairan meliputi kecerahan, salinitas, $\mathrm{pH}, \mathrm{BOD}, \mathrm{COD}$, nitrat, nitrit, fosfat, dan sulfat. Analisis kandungan unsur hara (nitrat, nitrit, fosfat, dan sulfat) serta BOD dan COD dilakukan dengan kolorimeter Hach DR/890 sesuai prosedur operasional alat (Hach, 1999). Nilai pH diukur dengan menggunakan pH meter Hanna (AOAC, 1990), salinitas diukur dengan refraktometer dan kecerahan diukur dengan secchi disk sesuai dengan metode yang dilakukan oleh Hutagalung et al. (1997).

Data hasil analisis kandungan logam berat selanjutnya dibandingkan dengan ambang batas residu logam berat yang diijinkan baik pada air (Anon., 2001; Anon., 2008a), sedimen (Anon., 2008b) maupun ikannya sebagai produk pangan (BPOM, 1989). Khusus terhadap ikan yang tercemar logam berat, selanjutnya dihitung batasan maksimum yang boleh dikonsumsi selama satu minggu berdasarkan ketentuan Provisional Tolerable Weekly Intake (PTWI) yang dikeluarkan oleh WHO (Anon., 2003). Ketentuan ini dipilih karena jenis kontaminan (logam berat $\mathrm{Hg}$, $\mathrm{Pb}, \mathrm{Cd}$, dan $\mathrm{Cu}$ ) besifat akumulatif (Anon., 1987; Darmono, 2001). Begitu juga dengan parameter kualitas lingkungan perairan. Terhadap parameter temperatur, $\mathrm{pH}, \mathrm{DO}, \mathrm{BOD}, \mathrm{COD}$ nitrit, nitrat, sulfit, dan fosfat dibandingkan dengan standar kualitas air untuk lingkungan biota perairan (Anon., 2001).

\section{HASIL DAN BAHASAN}

\section{Kandungan Logam Berat $\mathrm{Hg}, \mathrm{Pb}, \mathrm{Cd}$, dan Cu Pada Ikan}

Pada Tabel 2 disajikan hasil analisis logam berat pada ikan segar. Kandungan merkuri pada ikan segar

Tabel 2. Kandungan logam berat ( $\mathrm{Hg}, \mathrm{Pb}, \mathrm{Cd}$, dan $\mathrm{Cu})$ pada ikan

Table 2. Heavy metal residues ( $\mathrm{Hg}, \mathrm{Pb}, \mathrm{Cd}$ and $\mathrm{Cu}$ ) in fish samples

\begin{tabular}{|c|c|c|c|c|c|}
\hline $\begin{array}{l}\text { Bulant } \\
\text { Month }\end{array}$ & $\begin{array}{l}\text { Jenis ikan/ } \\
\text { Kind of fish } \\
\end{array}$ & $\begin{array}{c}\mathrm{Hg} \\
(\mathrm{ppb})\end{array}$ & $\begin{array}{c}\mathrm{Pb} \\
(\mathrm{ppb})\end{array}$ & $\begin{array}{c}C d \\
(p p b)\end{array}$ & $\begin{array}{c}\mathrm{Cu} \\
(\mathrm{ppb})\end{array}$ \\
\hline \multirow{2}{*}{ April 2005} & Haruan (Ophiocephalus striatus) & 162 & 102 & 12 & 140 \\
\hline & Utik (Batrachocephalus mino) & 11 & 58 & 20 & 273 \\
\hline \multirow{8}{*}{$\begin{array}{l}\text { September } \\
2005\end{array}$} & Haruan (Ophiocephalus striatus) & 3 & 6 & 8 & 32 \\
\hline & Layang (Rastrelliger kanagurta) & 5 & 24 & 70 & 52 \\
\hline & Selangat (Leiognathus brevirostris) & 4 & 19 & 33 & 13 \\
\hline & Biawan (Helostoma temminckii) & 3 & 12 & 14 & 3 \\
\hline & Sepat (Trichogaster leeri Blkr) & 3 & 41 & 8 & 129 \\
\hline & Bandeng (Chanos chanos) & 19 & 6 & 9 & 7 \\
\hline & Sepat (Trichogaster leeri Blkr) & 2 & $<1$ & 29 & 30 \\
\hline & Puyau (Anabas testudireus) & $<1$ & 2 & 3 & 17 \\
\hline & $\begin{array}{l}\text { Ambang batas }{ }^{*} / \\
\left.\text { Maxim um residue limit }{ }^{*}\right)\end{array}$ & 500 & 2,000 & 1,000 & 2,000 \\
\hline
\end{tabular}

*) BPOM/ Indonesian Food and Drug Control Agency (1989) 
berkisar 10-162 ppb yang berarti masih di bawah ambang batas yang diijinkan (500 ppb), tetapi pada jenis ikan haruan kandungan merkurinya sudah cukup tinggi (lebih dari $100 \mathrm{ppb}$ ) dan perlu mendapat perhatian. Hal ini karena kontaminasi logam berat dalam tubuh manusia bersifat akumulatif.

Pada sampel ikan haruan yang disampling pada bulan September, kandungan merkurinya relatif lebih rendah dibandingkan sampel ikan pada bulan April, yaitu berkisar 3-19 ppb. Rendahnya cemaran Hg pada ikan haruan yang diperoleh pada bulan September dapat disebabkan oleh dua hal, yaitu rendahnya akumulasi $\mathrm{Hg}$ karena umur ikan yang berbeda maupun akibat rendahnya cemaran $\mathrm{Hg}$ di lingkungan air dan sedimen pada bulan September dibandingkan bulan April (Tabel 3 dan 4). Cemaran merkuri yang masuk ke lingkungan dapat berasal dari limbah industri maupun kegiatan pertanian. Merkuri banyak digunakan pada produk cat, pembuatan klorin, industri kertas, dan elektronik, maupun pestisida. Cemaran merkuri bersifat toksik bagi biota perairan dengan toksisitas tertinggi dihasilkan dari senyawa metil merkuri (Anon., 1987).

Kandungan logam berat $\mathrm{Cd}, \mathrm{Cu}$, dan $\mathrm{Pb}$ pada daging ikan yang diambil pada bulan April maupun September cukup rendah dan masih di bawah ambang batas yang diijinkan. Ambang batas logam berat $\mathrm{Cu}$ dan $\mathrm{Pb}$ untuk produk pangan adalah $2.000 \mathrm{ppb}$ atau 2 ppm, sedangkan ambang batas logam berat $\mathrm{Cd}$ adalah 1.000 ppb (BPOM, 1989). Seperti halnya pada cemaran $\mathrm{Hg}$, cemaran logam $\mathrm{Pb}, \mathrm{Cd}$, maupun Cu pada ikan haruan yang diperoleh pada bulan September juga lebih rendah dari pada bulan April, begitu juga dengan cemaran logam $\mathrm{Pb}, \mathrm{Cd}$, dan $\mathrm{Cu}$ pada air maupun sedimen (kecuali Cd) (Tabel 3 dan 4).

Apabila dibandingkan dengan batasan maksimum yang boleh dikonsumsi selama satu minggu berdasarkan ketentuan Provisional Tolerable Weekly Intake (PTWI), maka ikan yang perlu dibatasi konsumsinya adalah ikan haruan (Ophiocephalus striatus) karena kandungan residu Hg-nya yang cukup tinggi. Batasan residu $\mathrm{Hg}$ yang boleh dikonsumsi selama 1 minggu adalah $300 \mu \mathrm{g} / 60 \mathrm{~kg}$ berat badan (Anon., 2003). Dengan kandungan residu $\mathrm{Hg}$ sebesar $162 \mathrm{ppb}$, maka konsumsi ikan ini paling banyak $1,8 \mathrm{~kg} /$ orang/minggu. Adapun ikan-ikan lain relatif masih aman karena masih dapat dikonsumsi hingga $5 \mathrm{~kg} /$ orang/minggu.

\section{Kandungan Logam Berat $\mathrm{Hg}, \mathrm{Pb}, \mathrm{Cd}$, dan Cu pada Air dan Sedimen}

Hasil analisis kandungan logam berat pada air muara S. Barito disajikan pada Tabel 3. Kandungan logam berat $\mathrm{Hg}, \mathrm{Pb}$, dan $\mathrm{Cu}$ air secara umum masih di bawah ambang batas yang diijinkan untuk kriteria kualitas air bagi biota perairan berdasarkan Peraturan Pemerintah Republik Indonesia Nomor 82 Tahun 2001 tentang Pengelolaan Kualitas Air dan Pengendalian Pencemaran Air yaitu 2 ppb (Anon., 2001). Akan tetapi jika dibandingkan dengan kriteria kualitas perairan laut untuk perlindungan biota perairan yang berlaku di negara-negara anggota ASEAN (Marine Water Quality Criteria for the Asean Region-for Aquatic Life Protection), kandungan $\mathrm{Hg}$ (bulan April dan Septem-

Tabel 3. Kandungan logam berat $(\mathrm{Hg}, \mathrm{Pb}, \mathrm{Cd}$, dan $\mathrm{Cu})$ dalam air

Table 3. Heavy metal residues ( $\mathrm{Hg}, \mathrm{Pb}, \mathrm{Cd}$ and $\mathrm{Cu}$ ) in water

\begin{tabular}{|c|c|c|c|c|c|}
\hline $\begin{array}{l}\text { Bulan/ } \\
\text { Month }\end{array}$ & $\begin{array}{l}\text { Stasiun/ } \\
\text { Station }\end{array}$ & $\begin{array}{c}\mathrm{Hg} \\
(\mathrm{ppb})\end{array}$ & $\begin{array}{c}\mathrm{Pb} \\
(\mathrm{ppb})\end{array}$ & $\begin{array}{c}\mathrm{Cu} \\
(\mathrm{ppb})\end{array}$ & $\begin{array}{c}C d \\
(p p b)\end{array}$ \\
\hline \multirow{6}{*}{ April 2005} & 1 & 1.45 & 18.2 & $<1$ & 7 \\
\hline & 2 & 1.41 & 23.9 & $<1$ & 11 \\
\hline & 3 & 1.23 & 5.7 & $<1$ & 11 \\
\hline & 4 & 1.90 & 32.1 & $<1$ & 8 \\
\hline & 5 & 1.74 & 17.0 & $<1$ & 11 \\
\hline & 6 & 0.87 & 10.8 & $<1$ & 12 \\
\hline \multirow{6}{*}{$\begin{array}{l}\text { September } \\
2005\end{array}$} & 1 & 1.50 & 2.6 & $<1$ & 57 \\
\hline & 2 & 0.61 & 2.5 & $<1$ & 53 \\
\hline & 3 & 0.61 & 1.9 & $<1$ & 54 \\
\hline & 4 & 0.84 & 3.1 & $<1$ & 54 \\
\hline & 5 & 0.61 & 2.7 & $<1$ & 49 \\
\hline & 6 & 0.34 & 2.0 & $<1$ & 44 \\
\hline \multicolumn{2}{|c|}{ Ambang batas/ } & $\left.2^{*}\right)$ & $\left.30^{*}\right)$ & $\left.20^{*}\right)$ & $\left.10^{*}\right)$ \\
\hline \multicolumn{2}{|c|}{ Maximum residue limit } & $\left.0.16^{* *}\right)$ & $\left.8.5^{* *}\right)$ & $\left.8^{* *}\right)$ & $10^{* *}$ \\
\hline
\end{tabular}

${ }^{*}$ Anon. (2001); ${ }^{* *}$ Anon. (2008a) 
ber) serta $\mathrm{Pb}$ (bulan April) telah melebihi ambang batas yaitu 0,16 ppb untuk $\mathrm{Hg}$ dan $8,5 \mathrm{ppb}$ untuk $\mathrm{Pb}$ (Anon., 2008a). Kegiatan penambangan emas tradisional diduga kuat sebagai sumber utama cemaran logam berat $\mathrm{Hg}$ di perairan $\mathrm{S}$. Barito. Hal ini ditunjukkan dengan banyaknya kegiatan penambangan emas liar di sepanjang S. Martapura, bagian hulu S. Barito (Radar Banjarmasin, 2008).

Kandungan logam Cd air muara S. Barito, terutama pada bulan September cukup tinggi dan telah melewati ambang batas yang diijinkan, baik oleh PP No.28/ 2001 maupun yang diacu oleh negara-negara anggota ASEAN yaitu 10 ppb (Anon., 2001; Anon., 2008a). Tingginya tingkat cemaran $\mathrm{Cd}$ ini kemungkinan disebabkan oleh tingginya intensitas cemaran logam $\mathrm{Cd}$ yang masuk ke lingkungan perairan. Logam Cd merupakan senyawa minor yang banyak digunakan pada berbagai produk, seperti produk elektronik, pewarnaan/cat, aki, fotografi, plastik, pestisida pertanian, dan bahan bakar (Anon., 2008d).

Hasil analisis kandungan logam berat $\mathrm{Hg}, \mathrm{Pb}, \mathrm{Cu}$ dan $\mathrm{Cd}$ sedimen disajikan pada Tabel 4. Kandungan
Kandungan logam Cu pada sedimen cenderung lebih tinggi dibandingkan dengan logam $\mathrm{Hg}, \mathrm{Pb}$ maupun $\mathrm{Cd}$. Hal ini kemungkinan karena senyawa Cu sangat labil di air dan lebih mudah membentuk kompleks organik $\left(\mathrm{CuCO}_{3}\right)$ kemudian mengendap dan berikatan dengan partikel sedimen (Anon., 2008c).

\section{Kualitas Air Muara S. Barito}

Pada Tabel 5 disajikan hasil analisis kualitas air muara S. Barito. Hasil analisis menunjukkan bahwa air $\mathrm{S}$. Barito cenderung bersifat asam dengan nilai $\mathrm{pH}$ berkisar antara 4,6-7,6. Pada bulan April air muara sungai lebih asam dari pada bulan September. Hal ini disebabkan karena pada bulan April volume air sungai relatif lebih tinggi karena pengaruh musim hujan dibandingkan pada bulan September. Di samping itu banyaknya lahan gambut di Kalimantan Selatan juga berpengaruh terhadap keasaman sungai akibat pencucian (leaching) oleh hujan. Kecerahan air muara sungai pada bulan April relatif lebih rendah dibandingkan pada bulan September. Rendahnya kecerahan lebih disebabkan oleh tingginya padatan

Tabel 4. Kandungan logam berat $(\mathrm{Hg}, \mathrm{Pb}, \mathrm{Cd}$, dan $\mathrm{Cu})$ pada sedimen

Table 4. Heavy metal residues $(\mathrm{Hg}, \mathrm{Pb}, \mathrm{Cd}$ and $\mathrm{Cu})$ in sediment

\begin{tabular}{|c|c|c|c|c|c|}
\hline $\begin{array}{l}\text { Bulan/ } \\
\text { Month }\end{array}$ & $\begin{array}{l}\text { Stasiun/ } \\
\text { Station }\end{array}$ & $\begin{array}{c}\mathrm{Hg} \\
(\mathrm{ppb})\end{array}$ & $\begin{array}{c}\mathrm{Pb} \\
(\mathrm{ppb})\end{array}$ & $\begin{array}{c}\mathrm{Cu} \\
(\mathrm{ppb})\end{array}$ & $\begin{array}{c}\text { Cd } \\
\text { (ppb) }\end{array}$ \\
\hline \multirow{6}{*}{ April 2005} & 1 & 3 & 182 & 2847 & 27 \\
\hline & 2 & 2 & 239 & 3663 & 106 \\
\hline & 3 & 3 & 373 & 3409 & 103 \\
\hline & 4 & 27 & 321 & 3292 & 35 \\
\hline & 5 & 36 & 170 & 3399 & 38 \\
\hline & 6 & 92 & 108 & 3069 & 149 \\
\hline \multirow{6}{*}{$\begin{array}{l}\text { September } \\
\quad 2005\end{array}$} & 1 & 6 & 5 & 438 & 27 \\
\hline & 2 & 119 & 11 & 622 & 87 \\
\hline & 3 & 4 & 7 & 758 & 59 \\
\hline & 4 & 9 & 5 & 828 & 34 \\
\hline & 5 & 11 & 4 & 341 & 11 \\
\hline & 6 & 2 & 6 & 665 & 202 \\
\hline \multicolumn{2}{|c|}{$\begin{array}{c}\left.\text { Ambang batas }{ }^{*}\right) \\
\text { Maximum residue limit }\end{array}$} & 410 & 450,000 & 390,000 & 5,100 \\
\hline
\end{tabular}

merkuri pada sedimen masih di bawah ambang batas yang diijinkan yaitu $410 \mathrm{ppb}$, begitu juga kandungan $\mathrm{Pb}, \mathrm{Cu}$, dan $\mathrm{Cd}$. Pada bulan September kandungan merkuri pada salah satu stasiun (stasiun 2) sudah tinggi, meskipun belum melewati ambang batas yang diijinkan. Secara umum kandungan logam $\mathrm{Pb}$ dan $\mathrm{Cu}$ pada bulan September lebih tinggi dari pada bulan April, sedangkan untuk logam $\mathrm{Hg}$ dan $\mathrm{Cd}$ relatif stabil. Hal ini kemungkinan karena intensitas cemaran antar jenis logam tersebut yang berbeda-beda. terlarut (suspended solid) dan bukan oleh blooming plankton. Hal ini dapat dilihat dari warna air sungai yang coklat serta berlumpur.

Salinitas air pada bulan April sangat rendah bahkan mendekati netral tetapi pada bulan September salinitas meningkat sampai 18 ppt. Hal ini disebabkan karena pada bulan April volume air sungai relatif tinggi dan stabil akibat pengaruh musim hujan sehingga hanya sedikit pengaruh air laut terhadap air tawar di muara 
Tabel 5. Hasil analisis kualitas air di muara S. Barito

Table 5. Water quality of Barito River

\begin{tabular}{|c|c|c|c|c|c|c|c|c|}
\hline $\begin{array}{l}\text { Bulan/ } \\
\text { Month }\end{array}$ & $\begin{array}{c}\text { Stasiun/ } \\
\text { Station }\end{array}$ & $\begin{array}{c}\text { Suhu/ } \\
\text { Tem perature } \\
\left({ }^{\circ} \mathrm{C}\right)\end{array}$ & $\mathrm{pH}$ & $\begin{array}{l}\text { Kecerahan/ } \\
\text { Transparency } \\
\text { (cm) }\end{array}$ & $\begin{array}{c}\text { Salinitas/ } \\
\text { Salinity } \\
\text { (ppt) }\end{array}$ & $\begin{array}{c}\text { DO } \\
(\mathrm{ppm})\end{array}$ & $\begin{array}{l}\text { BOD } \\
(p p m)\end{array}$ & $\begin{array}{l}\text { COD } \\
(\mathrm{ppm})\end{array}$ \\
\hline \multirow{6}{*}{ April 2005} & 1 & 28.7 & 5.6 & 50 & 0 & 22.5 & 7.1 & 138 \\
\hline & 2 & 29.1 & 4.4 & 50 & 2 & 20.5 & 10.5 & 160 \\
\hline & 3 & 28.8 & 5.7 & 50 & 0 & 19.7 & 13.2 & 29 \\
\hline & 4 & 29.6 & 5.4 & 50 & 2 & 17.7 & 9.1 & 296 \\
\hline & 5 & 29.5 & 4.6 & 50 & 2 & 10 & 4.5 & 65 \\
\hline & 6 & 29.2 & 4.9 & 50 & 1 & 6.9 & $<1$ & 50 \\
\hline \multirow{6}{*}{$\begin{array}{l}\text { September } \\
2005\end{array}$} & 1 & 28.5 & 7.4 & 120 & 10 & 4.5 & $<1$ & 68 \\
\hline & 2 & 29.0 & 7.2 & 100 & 10 & 7.1 & 2.6 & 65 \\
\hline & 3 & 28.0 & 7.3 & 50 & 18 & 4.0 & $<1$ & 102 \\
\hline & 4 & 28.8 & 7.5 & 60 & 14 & 4.5 & $<1$ & 137 \\
\hline & 5 & 29.1 & 7.6 & 100 & 12 & 3.5 & 2.1 & 77 \\
\hline & 6 & 29.3 & 7.6 & 100 & 7 & 5.0 & 1.7 & 79 \\
\hline \multicolumn{2}{|c|}{$\begin{array}{c}\text { Baku mutu*l } \\
\text { Standard quality }\end{array}$} & $\begin{array}{c}\text { Deviasi }{ }^{* *} / / \\
\left.\text { Deviation } 2^{* *}\right)\end{array}$ & $6.0-9.0$ & $>0.45$ & - & $>4.0$ & $<6.0$ & $<50$ \\
\hline
\end{tabular}

*) Anon. (2001)

**) Deviasi dari suhu lingkungan normal/Deviation from normal environment temperature

sungai. Kandungan COD (Chemical Oxygen Demand) cukup tinggi dan sudah melewati ambang batas untuk kelangsungan hidup biota perairan yaitu $50 \mathrm{ppm}$, tetapi oksigen terlarut (DO) umumnya masih memenuhi syarat ( $>4 \mathrm{ppm}$ ). Adapun kandungan BOD (Biological Oxygen Demand) pada umumnya masih di bawah ambang batas (6 ppm), kecuali di stasiun 1-4 pada bulan April. BOD, DO, dan COD merupakan parameter penting pada kualitas perairan bagi kelangsungan hidup biota yang hidup di dalamnya. Rendahnya DO serta tingginya BOD dan COD suatu perairan merupakan indikator tingginya tingkat cemaran biologis maupun kimiawi pada perairan tersebut (Vallejo et al., 1999; Effendi, 2003).

Pada Tabel 6 disajikan hasil analisis unsur hara air muara S. Barito. Dari tabel tersebut dapat dilihat

Tabel 6. Kandungan unsur hara $(\mathrm{ppm})$ air muara S. Barito

Table 6. Nutrient content (ppm) of the water at Barito River

\begin{tabular}{|c|c|c|c|c|c|c|}
\hline $\begin{array}{l}\text { Bulan/ } \\
\text { Month }\end{array}$ & $\begin{array}{l}\text { Stasiun/ } \\
\text { Station }\end{array}$ & $\begin{array}{l}\text { Nitrit/ } \\
\text { Nitrite }\end{array}$ & $\begin{array}{l}\text { Nitrat/ } \\
\text { Nitrate }\end{array}$ & $\begin{array}{l}\text { Amonial } \\
\text { Ammonia }\end{array}$ & $\begin{array}{c}\text { Sulfit/ } \\
\text { Sulphite }\end{array}$ & $\begin{array}{c}\text { Fosfat/ } \\
\text { Phosphate }\end{array}$ \\
\hline \multirow{6}{*}{ April 2005} & 1 & 0.04 & 0.10 & ND & 0.03 & 0.26 \\
\hline & 2 & 0.01 & 0.09 & 0.11 & ND & 0.31 \\
\hline & 3 & 0.04 & 0.09 & 0.03 & ND & 0.31 \\
\hline & 4 & 0.03 & 0.12 & 0.14 & 0.01 & 0.34 \\
\hline & 5 & 0.01 & 0.09 & 0.04 & 0.02 & 0.25 \\
\hline & 6 & 0.01 & 0.09 & 0.01 & ND & 0.33 \\
\hline \multirow{6}{*}{$\begin{array}{l}\text { September } \\
2005\end{array}$} & 1 & 0.03 & 0.08 & ND & 0.23 & 0.18 \\
\hline & 2 & ND & 0.51 & 0.04 & 0.02 & 0.51 \\
\hline & 3 & 0.05 & 0.38 & 0.08 & 0.01 & 0.38 \\
\hline & 4 & 0.02 & 0.10 & 0.07 & 0.01 & 0.10 \\
\hline & 5 & 0.09 & 0.80 & ND & 0.02 & 0.80 \\
\hline & 6 & 0.03 & 0.16 & 0.14 & 0.02 & 0.16 \\
\hline \multirow{2}{*}{\multicolumn{2}{|c|}{$\begin{array}{c}\text { Baku mutul } \\
\text { Standard quality }\end{array}$}} & $\left.0.06^{*}\right)$ & $\left.20^{*}\right)$ & $\left.0.02^{*}\right)$ & $\left.0.002^{*}\right)$ & $\left.1.00^{*}\right)$ \\
\hline & & $\left.0.05^{* *}\right)$ & $\left.0.06^{* *}\right)$ & $\left.0.07^{* *}\right)$ & - & $\left.0.045^{* *}\right)$ \\
\hline
\end{tabular}

Keterangan/Note: ND: tidak terdeteksi/not detected

${ }^{*}$ Anon. (2001); ${ }^{* *}$ Anon. (2008b) 
bahwa kandungan nitrit, nitrat, dan sulfit relatif rendah. Namun demikian kandungan amonia di beberapa stasiun pengamatan sudah ada yang melewati ambang batas yang diijinkan sesuai PP No.82/2001. Ambang batas berdasarkan PP tersebut untuk nitrit adalah $0,06 \mathrm{ppm}$, sulfida $0,002 \mathrm{ppm}$, nitrat $20 \mathrm{ppm}$, dan fosfat $1 \mathrm{ppm}$, sedangkan amonia 0,02 ppm (Anon., 2001).

Kandungan amonia yang melebihi ambang batas merupakan salah satu indikator terjadinya pencemaran biologis pada suatu perairan, mengingat amonia merupakan hasil dekomposisi senyawa biologis oleh mikroorganisme. Amonia merupakan racun yang berbahaya bagi biota perairan (Effendi, 2003). Apabila dibandingkan dengan kriteria kualitas perairan laut untuk biota perairan yang diacu oleh negara-negara anggota Asean, kandungan unsur hara nitrat dan fosfat telah melewati ambang batas (Anon., 2008b).

\section{KESIMPULAN}

Hasil penelitian menunjukkan bahwa kandungan logam berat $(\mathrm{Hg}, \mathrm{Pb}, \mathrm{Cd}$, dan $\mathrm{Cu})$ pada ikan dari perairan muara S. Barito masih di bawah ambang batas yang diijinkan sehingga aman untuk dikonsumsi. Namun demikian tingkat konsumsi untuk ikan haruan sudah harus mendapat perhatian karena kandungan logam Hg-nya sudah relatif tinggi.

Secara umum, kandungan logam berat pada air dan sedimen muara S. Barito pada stasiun-stasiun yang diteliti masih di bawah ambang batas yang diijinkan, kecuali kandungan $\mathrm{Cd}$ air pada bulan September. Untuk menjamin keamanan ikan-ikan yang ditangkap dari perairan ini untuk dikonsumsi, monitoring cemaran logam berat pada ikan maupun lingkungannya secara berkala sebaiknya dilakukan.

Hasil pengamatan unsur hara pada muara S. Barito pada umumnya masih cukup baik, kecuali kandungan amonia pada beberapa stasiun. Adapun kandungan COD air pada sebagian besar stasiun yang diamati, baik pada sampling bulan April maupun September, telah melebihi ambang batas yang layak untuk kehidupan biota perairan.

\section{DAFTAR PUSTAKA}

Anonymous. 1987. Canadian water quality guidelines. CCREM (Canadian Council of Resource and Environment Ministers). http://www.ec.gc.ca. Diakses tanggal 3 Desember 2008.

Anonim. 2001. Peraturan Pemerintah Republik Indonesia Nomor 82 Tahun 2001 tentang Pengelolaan Kualitas Air dan Pengendalian Pencemaran Air.
Anonymous. 2003. Summary and conclusion of the sixty-first meeting of Joint FAO/WHO Expert Commitee on Food Additives. www.who.int/pcs/jecfa. Diakses tanggal 18 Maret 2005.

Anonymous. 2004. Buyat Bay is polluted and a risk to the community: Highlights of the official joint investigation of Buyat Bay. A Joint Investigation Technical Team report, 9 November 2004. WALHI, Indonesian Mining Advocacy Network (JATAM), and Indonesian Center for Environmental Law (ICEL). http://www.walhi.or.id/eng/buyat_team_summary. Diakses tanggal 3 Desember 2008.

Anonymous. 2008a. Marine water quality criteria for the asean region (for Aquatic Life Protection). http:// www. aseansec.org/cme/Marine $\% 20$ Water $\% 20$ Quality\%20Criteria\%20for\%20the\%20ASEAN\%20 Region.pdf. Diakses tanggal 3 Desember 2008.

Anonymous. 2008b. Sediment quality chemical criteria. WAC 173-204-320. Washington state legislature. http://www.ecy.wa.gov/PROGRAMS/tcp/ smu/sed_chem.htm. Diakses tanggal 3 Desember 2008.

Anonymous. 2008c. Chemical properties of copper-health effects of copper-enviromental effects of copper. http://www.lenntech.com/Periodic-chartelements/Cu-en.htm\#Atomic\%20number. 5 pp. Diakses tanggal 18 Maret 2005.

Anonymous. 2008d. Numerical sediment quality assessment guidelines for florida coastal waters. www.dep.state.fl.us/waste/quick_topics/publications/ documents/sediment/volume1. Diakses tanggal 3 Desember 2008.

AOAC. 1990. Official Methods of Analysis of the Association of Official Analytical Chemist, $15^{\text {th }}$ ed. Arlington.

BPOM. 1989. Keputusan Ditjen Pengawasan Obat dan Makanan No.13725/B/SK.VII/1989.

Carere, M., Depropris, L., Funari, F., Musmeci, L., dan Onorati, F. 2008. Assessment and management of contaminated sediments in Italian marine coastal waters. Ann Ist Super Sanità. 44(3): 239-243

Darmono. 2001. Lingkungan Hidup dan Pencemaran, Hubungannya dengan Toksikologi Senyawa Logam. UI Press, Jakarta.

Eckenfelder, W.W. 1989. Industrial Water Pollution. Plenum Press. New York. 159 pp.

Effendi, H. 2003. Telaah Kualitas Air Bagi Pengelolaan Sumber Daya dan Lingkungan Perairan. Kanisius, Yogyakarta. $151 \mathrm{pp}$.

Hach. 1999. Dataloging Colorimeter Handbook. Hach Company, PO Box 608. Loveland, CO.

Hutagalung, HP., Permana, D.S., dan Riyono. 1997. Metode Analisis Air Laut, Sedimen dan Biota. Buku 2. Puslitbang Oseanologi. LIPI. 182 pp.

Kompas. 2003. 11 Sungai di Kalteng tercemar merkuri. http://www2.kompas.com/kompas-cetak/0307/09/ daerah/416802.htm. Diakses tanggal 18 Maret 2005.

Kompas. 2004. Bencana merkuri di Sungai Kahayan. 10 April 2004. http://64.203.71.11/kompas-cetak/ 0405/10/utama/1015623.htm. Diakses tanggal 18 Maret 2005. 
Kompas. 2005. Waspadai limbah merkuri akibat tambang emas liar. Kompas 25 Nopember 2005. http://www2.kompas.com/kompas-cetak/0511/25/ daerah/ 2240044.htm. Diakses tanggal 18 Maret 2006.

Perkin Elmer. 2000. Analytical Methods for Atomic Absorbtion Spectrometry. Perkin Elmer Instruments LLC. Singapore. 300 pp.

Radar Banjarmasin. 2008. Sungai Kalsel tercemar zat berbahaya. Kamis 12 Juni 2008. http:// www.kalselprov.go.id/v2/index.php/id/2008/06/12/ 342 /berita/sungai-kalsel-tercemar-zatberbahaya.phtml. Diakses tanggal 3 Desember 2008.

SNI 19-6964.2-2003. Cara Uji Merkuri (Hg) Secara Cold Vapour Dengan Spektrofotometer Serapan Atom
Atau Mercury Analyzer. Badan Standardisasi Nasional. 10 pp.

SNI 06-6989.46-2005. Cara Uji Kadar Timbal (Pb) Dengan Spektrofotometer Serapan Atom Secara Tungku Karbon. Badan Standarisasi Nasional. $6 \mathrm{pp}$.

Tempo. 2008. Tiga sungai di Kalimantan Tengah masih tercemar merkurium. Rabu, 13 Februari 2008. http:// www.te mpo.co.id/hg/nusa/2008/02/13/ brk,20080213-117413,id.html. Diakses tanggal 3 Desember 2008.

Vallejo-Pecharromán, B., Izquierdo-Reinaa, A., and Luque de Castrob, M.D. 1999. Flow injection determination of chemical oxygen demand in leaching liquid. Analyst. 124: 1261-1264. 


\section{LAMPIRAN 1/APPENDIX1. Lokasi pengambilan sampel di muara S. Barito/ Sampling location at Barito River}

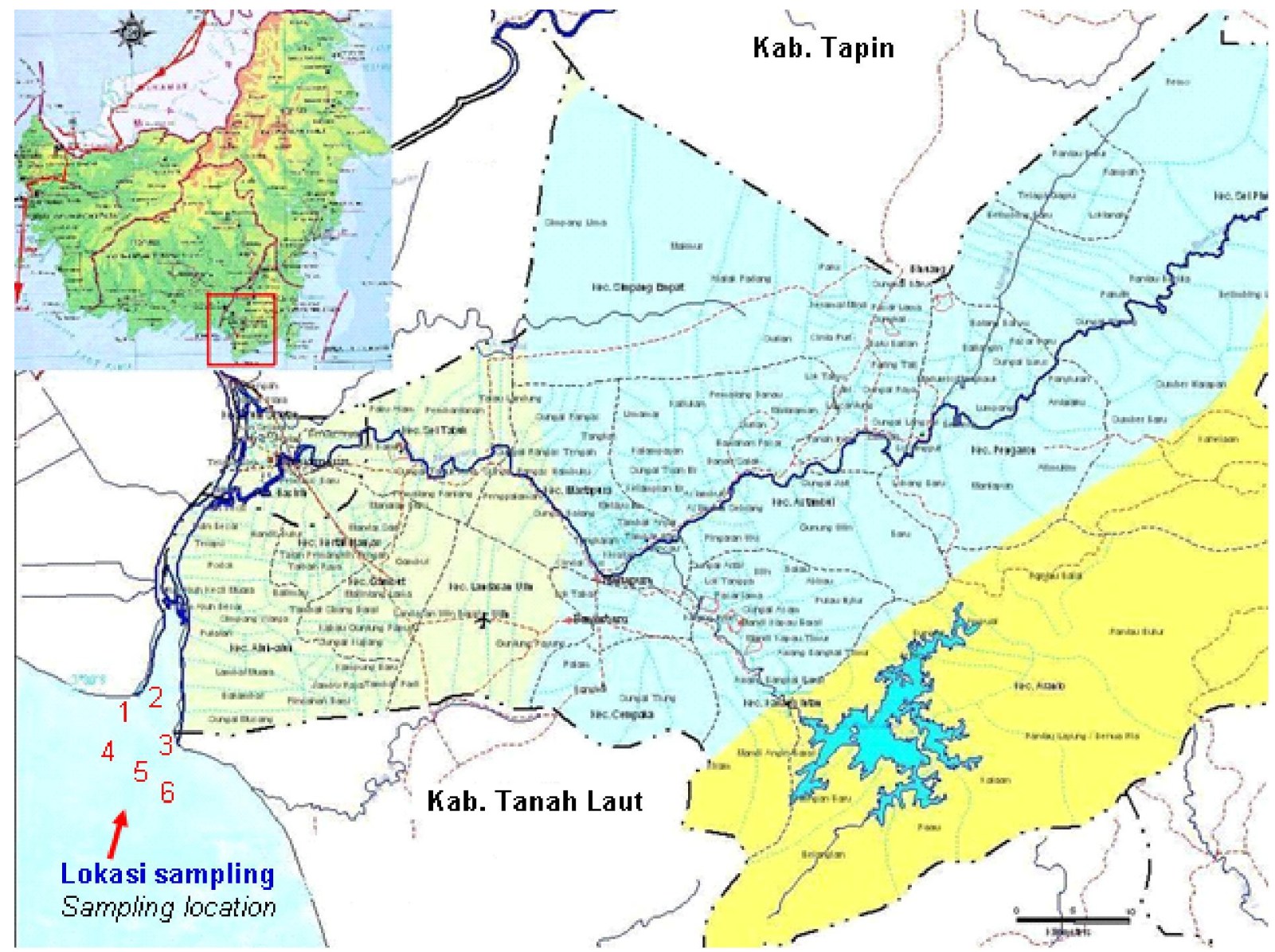

